This article has been published in a revised form in Parasitology https://doi.org/10.1017/S0031182020000128. This version is free to view and download for private research and study only. Not for re-distribution or re-use. (C) Cambridge University Press 2020. 


\section{Comparative mitogenomics of the zoonotic parasite Echinostoma revolutum resolves taxonomic relationships within the "E. revolutum" species group and the Echinostomata (Platyhelminthes: Digenea)}

Thanh Hoa Le ${ }^{1,2^{*}}$, Linh Thi Khanh Pham ${ }^{1}$, Huong Thi Thanh Doan ${ }^{1}$, Xuyen Thi Kim Le ${ }^{1}$, Weerachai Saijuntha ${ }^{3}$, R.P.V. Jayanthe Rajapakse ${ }^{4}$, Scott P. Lawton ${ }^{5}$

${ }^{1}$ Institute of Biotechnology (IBT); Vietnam Academy of Science and Technology (VAST), 18. Hoang

Quoc Viet Rd, Cau Giay, Hanoi, Vietnam

${ }^{2}$ Graduate University of Science and Technology (GUST); Vietnam Academy of Science and Technology (VAST), 18. Hoang Quoc Viet Rd, Cau Giay, Hanoi, Vietnam

${ }^{3}$ Walai Rukhavej Botanical Research Institute (WRBRI), Biodiversity and Conservation Research Unit, Mahasarakham University, Mahasarakham, 44150, Thailand

${ }^{4}$ Department of Veterinary Pathobiology, Faculty of Veterinary Medicine and Animal Science, University of Peradeniya, Peradeniya, Sri Lanka;

${ }^{5}$ Molecular Parasitology Laboratory, School of Life Sciences, Pharmacy and Chemistry, Kingston University London, Kingston Upon Thames, Surrey, KT1 2EE, UK;

*Corresponding author: Thanh Hoa Le; email: $\underline{\text { imibtvn@ gmail.com }}$ process. DOI: 10.1017/S0031182020000128 


\section{Abstract}

The complete mitochondrial sequence of 17,030 bp was obtained from Echinostoma revolutum and characterized with those of previously reported members of the superfamily Echinostomatoidea, ie., 6 echinostomatids, one echinochasmid, 5 fasciolids, one himasthlid and two cyclocoelids. Relationship within suborders and between superfamilies, such as Echinostomata, Pronocephalata, Troglotremata, Opisthorchiata, and Xiphiditata, are also considered. It contained 12 protein-coding, two ribosomal RNA, 22 transfer RNA genes, and a tandem repetitive consisting non-coding region (NCR). The gene order, one way-positive transcription, the absence of atp 8 and the overlapped region by 40 bp between nad4L and nad4 genes were similar as in common trematodes. The NCR located between tRNA ${ }^{\text {Glu }}$ (trnE) and cox3, contained 11, long (LRUs) and short repeat units (SRUs) (7 LRUs of 317 bp, 4 SRUs of $207 \mathrm{bp}$ each), and an internal spacer sequence between LRU7 and SRU4) specifying high level-polymorphism. Special DHU-arm missing tRNAs for Serine were found for both, $\mathrm{tRNA}^{\mathrm{S}(\mathrm{AGN})}$ and $\mathrm{tRNA}^{\mathrm{S}(\mathrm{UCN})}$. E. revolutum indicated the lowest divergence rate to E. miyagawai and the highest to Tracheophilus cymbius and Echinochasmus japonicus. The usage of ATG/GTG start and TAG/TAA stop codons, the AT composition bias, the negative ATskewness, and the most for Phe/Leu/Val and the least for Arg/Asn/Asp codons were noted. Topology indicated the monophyletic position of E. revolutum to E. miyagawai. Monophyly of Echinostomatidae and Fasciolidae was clearly solved with respect to Echinochasmidae, Himasthlidae and Cyclocoelidae which were rendered paraphyletic in the suborder Echinostomata.

Keywords: Echinostoma revolutum, Echinostomatidae, Echinostomatoidea, “37-collar-spined”, Mitochondrial genome, Phylogenetic analysis, Repeats, Skewness value. 


\section{Introduction}

Human echinostomiasis, is a global zoonotic foodborne trematodiasis caused by flukes within the Echinostoma revolutum group, and despite its worldwide distribution it is a particular public health problem in South East Asia (Chai, 2009; Toledo and Esteban, 2016). Echinostoma revolutum (Fröhlich, 1802) Rudolphi, 1809, is a member of the family Echinostomatidae (Platyhelminthes: Echinostomata), and the "E. revolutum" group is characterized by the "37-collarspines" found on the cercariae (Kostadinova, 2005; Georgieva et al., 2014). There are nine Echinostoma species within the E. revolutum group including Echinostoma caproni, Echinostoma echinatum, Echinostoma friedi, Echinostoma jurini, Echinostoma miyagawai, Echinostoma paraensei, Echinostoma parvocirrus, Echinostoma revolutum and Echinostoma trivolvis; while in other Echinostomatidae species the number of collar spines may vary, such as $25-29$ on Echinostoma hortense, 43 on Echinostoma malayanum, 41 - 45 on Hypoderaeum conoideum and 43 -50 on Echinoparyphium recurvatum (Chai et al., 2009; Saijuntha et al., 2011a). The similarity of these species within the E. revolutum complex usually required additional identification approaches for their discrimination, mostly enzymatic and molecular techniques (Saijuntha et al., 2011c; 2011a; Georgieva et al., 2014; Tkach et al., 2016).

The taxonomic status of E. revolutum is still controversial although recently a number of molecular studies have identified the parasite to be a highly cosmopolitan species comprising of several distinct geographical lineages corresponding to parasite populations with European, American and Southeast Asian origins (Saijuntha et al., 2011a; Georgieva et al., 2014; Nagataki et al., 2015; Faltýnková et al., 2015). The taxonomic identification and the phylogenetic assessment of each species within the "E. revolutum" group and as well between member taxa in the family Echinostomatidae requires accurate genomic data. Many attempts of interspecific clarification 
forthe echinostomatids, particularly for those withinthe "37-collar-spined" taxa have relied predominantly on tenuous morphological features (Georgieva et al., 2014; Nagataki et al., 2015; Faltýnková et al., 2015; Tkach et al., 2016). However, by using sing single 28S ribosomal DNA, limited short mitochondrial DNA sequences (mtDNA) or a combination of both, new cryptic echinostome species and the systematic relationships within and between members within the Echinostomatidae have been revealed as well as their association with the other families in the superfamily Echinostomatoidea (Platyhelminthes: Echinostomata) (Olson et al., 2003; Georgieva et al., 2013; 2014; Nagataki et al., 2015; Tkach et al., 2016). However, in order to provide a detailed account of current species and to taxonomically validate echinostomes more effectively it has been argued that genomic analyses could provide insights into the fine scale inter relationships between echinostome species (Detwiler et al., 2010; Faltýnková et al., 2015; Gordy and Hanington, 2019). Infact, the analyses of complete mitochondrial genomes to perform taxonomic and phylogenetic analyses of other members of the Echinostomata, as well as other trematode species, has been widely used and has provided not only a deeper understanding of the evolutionary relationships within and between trematode families but has also provided essential molecular markers for population genetics and diagnostics, crucial for modern epidemiological studies (Wey-Fabriziuset al., 2013; Georgieva et al., 2014; Faltýnková et al., 2015).

However, many morphologically similar species, and particularly, for those of the "collarspined" Echinostoma spp. in the Echinostomatoidea lack complete mitochondrial genomic data. Currently, only four of the nine species of the "E. revolutum" group, including E. caproni, E. paraensei, E. miyagawai, E. hortense (Saijuntha et al., 2011c), and a few species within the Echinostomata suborder have complete mitochondrial genomes available (Yang et al., 2015; Fu et al., 2019; Li et al., 2019a,b; Suleman et al., 2019). 
This current study determinedthe complete mitochondrial genome sequence of E. revolutum and correlatively characterized its genomic features and compared them with those previously reported in the superfamily Echinostomatoidea. A phylogeny for members of families in the suborders Echinostomata, Opisthorchiata, Troglotremata, Pronocephalataand Xiphidiata is provided.

\section{Materials and methods}

Samples, DNA extraction and species identification

Adult E. revolutum flukes were obtained from the intestines of the naturally infected domestic ducks from abattoirs in Khon Kaen province, Thailand. The flukes were thoroughly washed in physiological saline and morphologically identified based on size of the body and circumoral disc, the appearance of testes and the presence of "37-collar spines" around head (Miliotis and Bier, 2003; Georgieva et al., 2014). The worms were individually fixed in 70\% (v/v) ethanol and stored at $-20{ }^{\circ} \mathrm{C}$ until use. Subsequently, species were confirmed by molecular phylogenetic analyses using nuclear ITS-1, mitochondrial cox 1 and nad 1 markers (Saijuntha et al., 2011a; 2011b; Nagataki et al., 2015).

Total genomic DNA was extracted from individual worms using the DNA extraction kit (QIAGEN, Hilden, Germany) following the manufacturer's protocol. The E. revolutum-species used for mitochondrial sequencing in this study, belonged to the nad1-based analyzed E. revolutumEurasian lineage (Nagataki et al., 2015).

PCR strategies for obtaining the complete mitochondrial genome

The first, initial specific primer pairs (ERE1F/ERE2R; ERE3F/ERE4R; ERE5F/ERE6R) designed based on the conserved nucleotide sequencesaligned by those E. revolutum-mt sequences, cox1, nad1, rrnS (12S), respectively, available in GenBank and others, namely platyhelminth- 
universal primers (TRECOBF; TRECOBR; GLYF; GLYR) previously described in Le et al. (2019) were used. They were paired to bind on the target regions for amplification of long PCR of 4.0 -7.5 $\mathrm{kb}$ or short of $<4.0 \mathrm{~kb}$ overlapping fragments. The sequence data obtained were used to design further E. revolutum- specific primers (Table 1).

All reagents and kits used in this study were from Thermo Fisher Scientific Inc. (Waltham, MA, USA), including Phusion for long, and Dream Taq PCR Master Kits for short PCRs. PCRs were prepared in $50 \mu \mathrm{L}$ volume with the addition of DMSO to $1.5 \%$, and performed in a MJ PTC100 Thermal Cycler. Long-PCRs were conducted with initial denaturation at $98^{\circ} \mathrm{C}$ for $30 \mathrm{sec}$, followed by 35 cycles, each consisting of denaturation step for $30 \mathrm{sec}$ at $98^{\circ} \mathrm{C}$, annealing/extension step at $72{ }^{\circ} \mathrm{C}$ for $6-8$ min and final extension at $72{ }^{\circ} \mathrm{C}$ for $10 \mathrm{~min}$ (in some cases, at $68{ }^{\circ} \mathrm{C}$ ). ShortPCRs were started at $95^{\circ} \mathrm{C}$ for $5 \mathrm{~min}$, followed by 35 cycles consisting of denaturation for $1 \mathrm{~min}$ at $94{ }^{\circ} \mathrm{C}$, annealing at $52{ }^{\circ} \mathrm{C}$ for $1 \mathrm{~min}$, extension at $72{ }^{\circ} \mathrm{C}$ for 2 to $5 \mathrm{~min}$, and a final extension at 72 ${ }^{\circ} \mathrm{C}$ for 7 or $10 \mathrm{~min}$. A negative (no-DNA) control was included in some cases. The PCR products (5-10 $\mu \mathrm{L}$ of each) were examined on a1\% agarose gel, stained with ethidium bromide, and visualized under UV light (Wealtec, Sparks, NV, USA).The primer-walking sequencing was applied until the complete sequence for the whole fragment, and the overlapping assembly was used to complete the mitochondrial genome.

\section{Characterization of mitogenomic features}

Protein-encoding genes (PCGs) were identified by alignment with the available mt genomes of other Echinostoma trematode species and ATG/GTG as start and TAA/TAG as stop codons were used to define gene boundaries. Protein-encoding genes were translated using the echinoderm/flatworm mitochondrial genetic code: translation Table 9 in GenBank. Nucleotide and codon composition were analyzed with MEGA 7.0 (Kumar et al., 2016) and codon usage for all 
PCGs was determined with the program GENE INFINITY (Codon Usage:

http://www.geneinfinity.org/sms/sms_codonusage.html). Nucleotide percentage (\%) for comparison of individual/ concatenated PCGs and mitochondrial ribosomal genes (MRGs) between E. revolutum and 14 representative members of the superfamily Echinostomatoidea (Table 2) was determined by using GENEDOC 2.7 for alignment, Gblocks 0.91b (Castresana, 2000) (online accession at http://molevol.cmima.csic.es/castresana/Gblocks_server.html) for picking the best quality block $(10,112 \mathrm{bp})$ and MEGA 7.0 for percentage estimation.

The transfer RNA genes (tRNA or $t r n$ ) were identified using tRNAscan-SE 1.21 program (www.genetics.wustl.edu/eddy/tRNAscan-SE/) (Lowe and Eddy, 1997); ARWEN at http://mbioserv2.mbioekol.lu.se/ARWEN/ (Laslett and Canback, 2008) for finding the best final tRNA sequences and secondary structures. Any tRNAs not detected by these programs were found by inspection of the sequences, based on the alignment with sequences of other trematode and by their potential formation of tRNA configuration. The ribosomal $16 \mathrm{~S}(r r n \mathrm{~L})$ and $12 \mathrm{~S}(r r n \mathrm{~S}) \mathrm{RNA}$ genes were recognized as described in Le et al. (2019) in the region located between tRNA ${ }^{\text {Thr }}(\operatorname{trnT})$ and $\operatorname{cox} 2$ separated by $\mathrm{RRNA}^{\mathrm{Cys}}(\operatorname{trn} \mathrm{C})$, respectively.

The nucleotide composition, AT and GC content for concatenated 12 PCGs (not excluding the overlapped sequences between nad $4 \mathrm{~L}$ and nad4), 2 MRGs and complete mt genome for 15 members of the Echinostomatoidea were determined by MEGA7.0, and the AT and GC skewness values (from -1 to +1 ) calculated according to the formula by Perna and Kocher $(1995)($ AT skew $=(\mathrm{A}+\mathrm{T}) /(\mathrm{A}-\mathrm{T})$ and $\mathrm{GC}$ skew $=(\mathrm{G}+\mathrm{C}) /(\mathrm{G}-\mathrm{C})$.

The non-coding region (NCR) was determined by recognition of boundaries between tRNA $^{\text {Glu }}(\operatorname{trn} \mathrm{E})$ and $\operatorname{cox3}$. Tandem Repeat Finder v3.01 (Benson, 1999) was used to detect repeat 
units (RUs) in the NCR of mitogenome of E. revolutum in this study and other Echinostoma spp. and digeneans which were not available in GenBank or not previously reported. Phylogenetic analyses

Concatenated amino acid sequences of the 12 PCGs of E. revolutum and 44 species from 13 families (ie., Echinostomatidae, Fasciolidae, Himasthlidae, Echinochasmidae, Cyclocoelidae, Paramphistomidae, Gastrothylacidae, Notocotylidae, Troglotrematidae/(Paragonimidae), Heterophyidae, Opisthorchiidae, Diclocoeliidae and Schistosomatidae) in the superfamilies of Echinostomatoidea, Paramphistomoidea, Pronocephaloidea, Treglotrematoidea, Opisthorchioidea and Gorgoderoidea were aligned for phylogenetic analysis. Sequence of Schistosoma haematobium (Digenea: Schistosomatidae) was chosen as an outgroup (Littlewood et al., 2006). The alignment was constructed by GENEDOC2.7, confirmed by MAFFT 7.122 (Katoh and Standley, 2005) and finalized by Gblocks $0.91 \mathrm{~b}$. The final alignment block of $2993-3025$ amino acids without poorly aligned regions, was picked out for phylogenetic analysis. Tree was constructed using maximum likelihood by MEGA 7.0 with bootstrap of 1000 replications. The substitution model with the best score according to the Bayesian information criterion was the Jones, Taylor \& Thornton $+\mathrm{F}+\mathrm{G}+\mathrm{I}$ model, with residue frequencies estimated from the data $(+\mathrm{F})$, rate variation along the length of the alignment $(+G)$ and allowing for a proportion of invariant sites $(+\mathrm{I})$.

\section{Results}

Gene organization and genomic features

The complete mitochondrial genome of E. revolutum was shown to be $17,030 \mathrm{bp}$ in size (GenBank accession no. MN496162) (Fig. 1). As common in other trematodes, the E. revolutum mitogenome has one-direction transcription, similar gene organization and content with the exception of African Schistosoma spp. It comprises of 12 protein coding genes (atp6, cox1-3, cytb, 
nad1-6, nad4L), two ribosomal RNA ( $r r n \mathrm{~L}$ and $r r n \mathrm{~S})$ and 22 transfer RNA genes (tRNA or $t r n$ ) similar to those of common digeneans (Table 2).

Echinostoma revolutum has typical mtstructural features of the platyhelminths and does not contain atp8 and has the overlapped region between nad4L and nad4 genes by 40 bp (Table 2). Five protein-coding genes used GTG (nad4L, nad2, nad1, cox1, nad5) and other seven used ATG as start codons; and 7 genes used TAG and 5 used TAA for termination. Boundaries between cytb and $n a d 4 \mathrm{~L}$, between tRNA ${ }^{\text {Asp }}$ and $n a d 1$, from tRNA ${ }^{\text {Thr }}$ to $r r n S(12 S)$, covering $r r n L(16 S)$, tRNA ${ }^{\text {Cys }}$ genes, and between repeats in the NCR are continuous whilst there are large intergenic spacers of 33 or 30 bp between other genes ( $\operatorname{cox} 1$ and $\mathrm{tRNA}^{\mathrm{Th}}$; and $\mathrm{tRNA}^{\mathrm{Val}}$ and $\left.\mathrm{tRNA}{ }^{\mathrm{Ala}}\right)$, respectively.

The mt genome of E. revolutum encodes twenty-two transfer RNAs, ranging from 60 $\left(\mathrm{tRNA}^{\mathrm{S} 1(\mathrm{AGN})}\right)$ to 71 nucleotides (tRNA $\left.{ }^{\mathrm{His}}\right)$. Twenty have common 'cloverleaf' folding into secondary structures with the complete four-arms but two for Serine, $\operatorname{tRNA}^{\mathrm{S1}(\mathrm{AGN})}$ and tRNA $^{\text {S2(UCN) }}$, possess special forms missing DHU-arms (Table 2; SFig. 1).Two ribosomal RNA genes, $r r n \mathrm{~L}(977 \mathrm{bp})$ and $r r n \mathrm{~S}\left(756 \mathrm{bp}\right.$ long) are located between the tRNA ${ }^{\mathrm{Thr}}$ and $\operatorname{cox} 2$, separated by tRNA ${ }^{\text {Cys }}$. The order of the mitochondrial DNA block of $\left[\operatorname{cox} 1-\mathrm{tRNA}{ }^{\mathrm{Thr}}-\mathrm{rrn \textrm {L }}\right.$ tRNA $^{\text {Cys }}$-rrnS-cox2-nad6] is highly conserved in all the trematodes, including E. miyagawai, Ech. japonicus, Fa. magna, F. hepatica, F. gigantica and Asian Schistosoma spp. (Le et al., 2001; 2002; 2016; Liu et al., 2014; Ma et al., 2016; Fu et al., 2019; Li et al., 2019b). Base composition and comparative analyses

The base composition was A (18.81\%), T (47.40\%), G (23.50) and C (10.29\% in the mt genome of E. revolutum and the A+T content was $62.21 \%$ for PCGs and their skewness values were -0.46 for $\mathrm{A}+\mathrm{T}$ and 0.391 for $\mathrm{G}+\mathrm{C}$, respectively. MRGs showed similar percentage of 
overall $\mathrm{A}+\mathrm{T}(62.73 \%)$ and $\mathrm{G}+\mathrm{C}(37.27 \%)$ but their skewness values were considerably different $(-0.179 / \mathrm{A}+\mathrm{T}$; and $0.275 / \mathrm{G}+\mathrm{C})$ due to the bias use of A over T in PCGs than in MRGs (Table 3).

The divergence rate (\%) inferred from the nucleotide pairwise comparison of 12 individual mitochondrial protein-coding and 2 ribosomal genes between E. revolutum and 14 members of Echinostomatoidea indicated that the rate was the lowest level of divergence was between E. revolutum and E. miyagawai (8.99\%/nad4L - 18.4\%/nad4; 6.63\%/rrnS 8.93\%/rrnL), and in average, 14.89\%/PCGs for protein-coding genes and 8.29\%/MRGs for ribosomal genes, respectively.

The highest nucleotide sequence divergence between E. revolutum and Echinostomatoidea trematodes was $39.5 \%$ in comparison with Tracheophilus cymbius (Cyclocoelidae) and 38.16\% for Ech. japonicus (Echinochasmidae) for PCGs (Table 4). Overall, the nucleotide sequence of E. revolutum in each gene differed from $6.63 \% / \mathrm{rrnS} /($ E. miyagawai) to $59.89 \% / n a d 5 /(T$. cymbius $)$. Within the Echinostomatidae, the interspecific variation does not exceed $37 \%$, as seen between atp 6 genes of E. revolutum and $H$. conoideum.

The codon usage in mtDNAs of all the Echinostomatidae trematodes (E. revolutum; E. caproni; E. miyagawai; E. paraensei; Echinostomasp. JM-2019; A. sufrartyfex; H. conoideum) is biased to the use of TTT (for Phenylanine), TTG (for Leucine) and GTT (for Valine). Multiple Thymine (T) in use in these codons facilitates the mostly used frequency (from 5.96\% GTT/Val in H. conoideum to $10.65 \%$ TTT/Phe in E. caproni). The least frequently used codons, comprising mostly G and C, are CGC (for Arginine), AAC (for Asparagine) and GAC (for Aspartic acid), ranging from one to two $(0.03-0.06 \%)$ to six to seven $(0.18-0.21 \%)$ were noted. Clear bias was seen to the use of TAG ( 7 to 12 codons) for termination of 12 PCGs rather than TAA (0 to 5) in mt PCG genes of all the eight echinostomids (STable 1). 
Polymorphism featured by repeat units in non-coding regions of Echinostoma spp.

The non-coding region (NCR) of E. revolutum was identified by recognition of boundary of tRNA ${ }^{\text {Glu }}(\operatorname{trn} \mathrm{E})$ and $\operatorname{cox} 3$ gene, which is of 3,549 bp in length, perhaps the longest in the mt genomes of the echinostomid flatworm sever fully sequenced to date (Table 2, 5). The NCR of this species possesses seven long, identical repeat units (LRU1 to LRU7, $317 \mathrm{bp}$ each) and four short, identical, repeat units (SRU1 to SRU4, each of $207 \mathrm{bp)}$ ) tandemly arranged after each other (Table 2, 5; Fig. 1; GenBank: MN496162). Between LRU7 and SRU4, there is a linking region of an internal spacer sequence of $377 \mathrm{bp}$ which contained of $188 \mathrm{bp}$, partial of LRU (designated as IntS-half1) and $189 \mathrm{bp}$, partial of SRU (IntS-half2). A unique sequence region of 130 nucleotides continuously occurs between SRU1 and $\operatorname{cox} 3$ (Table 2; Fig. 1).

Tandem repeat units were also found in E. miyagawai (2 RUs, 319 bp each), in $E$. paraensei (at least 3 RUs, 206 bp each in the partially sequenced NCR), in Echinostoma sp. JM2019 (5 LRUs, 245 bp each and 2 SRUs, 166 bp each), in A. sufrartyfex (2 RUs, 144 bp each) which is variable in numbers and length (Table5). The size of mt genome differed among echinostomes and digeneans, this is due to the variable length of their non-coding regions rich in multiple repeat units (Table 3).

Phylogenetic analysis

The topology of the phylogenetic tree of taxonomic relationship indicated clear positions of five suborders, including Echinostomata, Pronocephalata, Treglotremata, Opisthorchiata and Xiphidiata where E. revolutum, grouped in a monophyletic subclade as a sister taxa to $E$. miyagawai and paraphyletic to the other echinostomatids in the Echinostomatidae (Fig. 2). Monophyly of Echinostomatidae and Fasciolidae clearly resolved with respect to Echinochasmidae, Himasthlidae and Cyclocoelidae; these were rendered paraphyletic in the suborder Echinostomata 
(Fig. 2). The high nodal bootstrap values well supported clear taxonomic relationships of the ' $E$. revolutum' group in the Echinostomatoidea and this seemed to be in the paraphyletic position with all the other superfamiles, Pronocephalata, Treglotremata, Opisthorchiata and Xiphidiata in the digenean order Plagiorchiida.

\section{Discussion}

The complete mitochondrial genome of E. revolutum (Fröhlich, 1802) Rudolphi, 1809, was $17,030 \mathrm{bp}$ in size; the longest of all the Echinostomatoidea to date sequenced, although the mitogenome of E. paraensei (KT008005) was claimed longer, 20,298 bp, but some of 5,600 nucleotides were only of estimation (Liu et al., 2014; Yang et al., 2015; Ma et al., 2016; 2017; Le et al., 2016; Fu et al., 2019; Li et al., 2019a,b; Suleman et al., 2019).

The length of the mt genome of E. revolutum seemed to be one of the longest among trematodes fully obtained to date, shorter than the estimated, partially sequenced congener $E$. paraensei, but was slightly longer than other echinostomids, including H. conoideum (Yang et al., 2015), E. miyagawai (Fu et al., 2019; Li et al., 2019b), Ech. japonicus (Le et al., 2016) and two cyclocoelids, Uvitellina sp. and T. cymbius (Suleman et al., 2019; Li et al., 2019a). It was considerably longer than many fasciolids, such as Fas. buski (GenBank: KX169163) (Ma et al., 2017), F. gigantica (KF543342), F. hepatica (AF216697), Fasciola/Fascioloides jacksoni (KX787886), and Fa. magna (KU060148) (Liu et al., 2014; Ma et al., 2016).

The tRNAs which were lacking DHU-arm for Serine in E. revolutum are usually found in many digenean mitogenomes, ie. Echinococcus granulosus, F. hepatica (Le et al., 2001; 2002), Fa. magna (Ma et al., 2016), E. miyagawai (Li et al., 2019b) and Fa. jacksoni (KX787886).

The gene organization, comparative description of genomic features with other members of Echinostomatidae, particularly, with E. miyagawai isolates (from Hunan and Helongjang of China) 
and those of the digenean Echinostomata were presented. In mtDNA sequence of E. revolutum, the nucleotide usage clearly biased to AT, and thus, constituting their negative skewness. Skewness values for $\mathrm{A}+\mathrm{T}$ are consistent with those of E. miyagawai, E. paraensei (Echinostomatidae) and Acanthoparyphium sp. WAK-2018 (Himasthlidae), considerably higher than all of the members of Fasciolidae, slightly higher than other echinostomatids (E. caproni; Echinostoma sp. JM-2019; A. sufrartyfex; and H. conoideum), echinochasmid (Ech. japonicus) but lower than the cyclocoelid $T$. cymbius. The $\mathrm{G}+\mathrm{C}$ content and skewness of E. revolutum seemed to be of the lowest $(\mathrm{GC}$ skew $=$ 0.391) among all species studied here (Table 3).

Echinostoma revolutum and E. miyagawai shared more common genomic features than others in the genus Echinostoma and family Echinostomatidae. The pattern of the usage of ATG/GTG start and TAG/TAA stop codons, the AT composition bias, the negative AT-skewness, and the most for Phe/Leu/Val and the least for Arg/Asn/Asp codons in E. revolutum were usual and similar to members of Echinostoma and digenean trematodes.

The presence of 11 tandem repeats in non-coding region (GenBank: MN496162) made the NCR of E. revolutum longer and more complex relative to other echinostomatids. The repetitive sequence-richness in NCR was a typical genomic feature commonly seen in a number of species, specifying high level-polymorphism in Echinostomata and other digeneans (Table 5) (Le et al., 2001; 2016; 2019; Liu et al., 2014; Ma et al., 2016; 2017; Fu et al., 2019). For some of Echinostoma spp. which had their complete mitogenomes fully sequenced to date, the number of repeat units was fewer or absent, and the length of the NCR was less than those of E. revolutum.

The actual size of the mitogenomes of other echinostomids may have been an under estimation in some of the original individuals sampled as several of the repeat elements may not have been considered or incorporated in the initial analyses (Yang et al., 2015; Fu et al., 2019; and 
GenBank: MH212284; KY548763; AP017706) (Table 5), as a result of missing a part of the region containing more repeat units. The missing part of the NCR may be the result of an inaccurate PCR experiment that was carried out without verification (Oey et al., 2019; Kinkar et al., 2019). In E. revolutum, the NCR was successfully amplified and accurately sequenced from a number of the verified PCR products and the repeat units were confirmed to occur in the expanded NCR giving its complete mt DNA sequence as the second longest among members of the Echinostomatidae.

The such repetitive regions have also occurred in the mt DNA of, for example, Echinococcus granulosus G1 with the addition of a $4.4 \mathrm{~kb}$ tandem repeat region consisting ten repeat units (Kinkar et al., 2019), or Paragonimus westermani from the Arunachal Pradesh State (India), with the full $\mathrm{mt}$ DNA of $20.3 \mathrm{~kb}$ comprising of a long repetitive region in the isolate of the East Siang district (Oey et al., 2019) instead of 14,965 bp in the isolate of the Changlang District (Biswal et al., 2014). However, it should be noted that the length and number of repeats are genetically variable between geographical isolates of a trematode species, as seen in P. ohirai and P. westermani (Le et al., 2019; Oey et al., 2019) and there are no quantity of repeats in individuals to be considered fixed. In many other taxa of trematodes reported to date, for example, Ech. japonicus, F. hepatica, Fas. buski, Fa. magna, P. ohirai, repetitive units either of long or short sequences and even various quantity within a species, frequently occurred and commonly found (Le et al., 2001; 2016; 2019; Liu et al., 2014; Ma et al., 2016; 2017; Fu et al., 2019; Li et al., 2019b). Interestingly, none of repetitive units was found in E. caproni, H. conoideum and T. cymbius (Yang et al., 2015; Li et al., 2019a). The occurrence of repetitive sequences in tandem order in many species, certainly are of the most interesting genomic features, specifying the high levelpolymorphism in the NCRs of digenean trematodes. Also, although tandem repeats are common in eukaryotic mitochondrial genomes, their functional role is still not completely understood. 
However, they do appear to have an accelerated rate of evolution and some involvement in the regulation of the mtDNA coding region (Lunt et al., 1998; Gemayel et al., 2010).

The phylogenetic tree presented in this study indicated the precise placement of $E$. revolutum in the Echinostomatidae, matched closely the relationships described in previous studies using nuclear ribosomal sequences (Olson et al., 2003; Tkach et al., 2016). The Fasciolidae and Echinostomatidae are always sister groups within the Echinostomata, as are the Heterophyidae and Opisthorchiidae (within the Opisthorchiata). The echinostomatid species in the tree were also clustered well in the phylogenetic studies by Liu et al. (2019) and Fu et al. (2019) using the complete mitochondrial genome sequences with one exception. The exception was, in their studies, the closeness of E. myiagawai and E. paraensei (sister groups), however in this current study, E. myiagawai is closely associated with E. revolutum. This discrepancy of echinostomatid relationships was explained by the lack of mt DNA of E. revolutum for comparative analysis at that time. In our present study the echinostomid relationship was also resolved, that the "37-collar-spines”' 'E. revolutum' group members, E. revolutum, E. myiagawai, E. caproni and E. paraensei, were clustered together indicating their genetically close relationships, rather than other Echinostoma species, A. sufrartyfex, Echinostoma sp. JM2019 and H. conoideum (Fig. 2). This relatedness of the 'revolutum' group is reflected by the very low divergence rate $(\%)$ of individual and concatenated protein-coding (PCGs) and mitoribosomal genes (MRGs) between E. revolutum and E. myiagawai/E. caproni, which varied within the least, $6.63 \%$ and the highest, $20.03 \%$, compared to the rate of more than $20 \%$ in all cases of other echinostomid species (Table 4). 


\section{Conclusion}

The fully annotated mitogenome of E. revolutum and comparative description of mitogenomic features of echinostomids in the present study provide well-supported resolution of relationships of the "revolutum" group and the Echinostomata in relation of other suborders in Plagiorchiida (Platyhelminthes: Digenea). The characterization revealed the taxonomic and phylogenetic relationships of E. revolutum to the echinostomatid species and other members in Echinostomatoidea. Molecular analyses of recently available mitogenomic sequences from Echinostomatidae, Himasthlidae and Cyclocoeliidae and comparisons of genetic features have emphasized the "revolutum" group to be complex, but phylogenetic analysis has confirmed monophyly Echinostomatidae and Fasciolidae. Data from this species and additional Echinostoma spp. will be useful for clarification and reappraisal of the complex echinostome group and for the use in the field of molecular taxonomic, diagnostic, systematic, epidemological, phylogenetic and population studies of trematodes.

Supplementary material. The supplementary material for this article can be found at: https://www.cambridge.org/core/journals/parasitology

\section{Author ORCIDs: https://orcid.org/0000-0003-3841-368X}

Acknowledgements. We express our thanks to colleagues and technicians for contribution to our laboratory work. We would also like to express our thanks to the external reviewers for their extremely informative and constructive comments.

Author contributions. Thanh Hoa Le conceived the study, analyzed the final data, prepared figures and tables and wrote the manuscript; Linh Thi Khanh Pham, Huong Thi Thanh Doan, 
Xuyen Thi Kim Le conducted laboratory works and sequence analyses. Weerachai Saijuntha collected, molecularly identified and provided specimens. R.P.V. Jayanthe Rajapakse, Weerachai Saijuntha reviewed the drafts. Scott P. Lawton and Thanh Hoa Le completed and approved the manuscript. All authors read and approved the final manuscript.

Financial support. This research is funded by Vietnam National Foundation for Science and Technology Development (NAFOSTED) under grant number 108.02-2017.09 (PI: ThanhHoa Le).

Conflict of interest. None.

Ethical standards. None 


\section{REFERENCES}

Benson G (1999) Tandem repeats finder: a program to analyze DNA sequences. Nucleic Acids Research 27, 573-580. DOI: 10.1093/nar/27.2.573.

Biswal DK, Chatterjee A, Bhattacharya A and Tandon V (2014) The mitochondrial genome of Paragonimus westermani (Kerbert, 1878), the Indian isolate of the lung fluke representative of the family Paragonimidae (Trematoda). Peer J 2, e484. DOI: 10.7717/peerj.484.

Castresana J (2000) Selection of conserved blocks from multiple alignments for their use in phylogenetic analysis. Molecular Biology and Evolution 17, 540-552. DOI: 10.1093/oxfordjournals.molbev.a026334.

Chai JY (2009) Echinostomes in humans. In: Fried B, Toledo R (eds). The Biology of Echinostomes. New York, USA: Springer; 2009. pp. 147-183.

Detwiler JT, Bos DH and Minchella DJ (2010) Revealing the secret lives of cryptic species: examining the phylogenetic relationships of echinostome parasites in North America. Molecular Phylogenetics and Evolution 55, 611-620. DOI: 10.1016/j.ympev.2012.12.015.

Faltýnková A, Georgieva S, Soldánová M and Kostadinova A (2015) A re-assessment of species diversity within the 'revolutum' group of Echinostoma Rudolphi, 1809 (Digenea: Echinostomatidae) in Europe. Systematic Parasitology 90, 1-25. DOI: 10.1007/s11230-0149530-3.

Fu YT, Jin YC, Li F and Liu GH (2019) Characterization of the complete mitochondrial genome of the echinostome Echinostoma miyagawai and phylogenetic implications. Parasitology Research 118, 3091-3097. DOI: 10.1007/s00436-019-06417-4. 
Gemayel R, Vinces MD, Legendre M and Verstrepen KJ (2010) Variable tandem repeats accelerate evolution of coding and regulatory sequences. Annual Review of Genetics $\mathbf{4 4 ,}$ 445-477. DOI: 10.1146/annurev-genet-072610-155046.

\section{Georgieva S, Faltýnková A, Brown R, Blasco-Costa I, Soldánová M, Sitko J, Scholz T and} Kostadinova A (2014). Echinostoma 'revolutum' (Digenea: Echinostomatidae) species complex revisited: species delimitation based on novel molecular and morphological data gathered in Europe. Parasites \& Vectors 7, 520. DOI:10.1186/s13071-014-0520-8.

\section{Georgieva S, Selbach C, Faltýnková A, Soldánová M, Sures B, Skírnisson K and}

Kostadinova A (2013). New cryptic species of the 'revolutum' group of Echinostoma (Digenea: Echinostomatidae) revealed by molecular and morphological data. Parasites \& Vectors 6, 64. DOI: 10.1186/1756-3305-6-64.

Gordy MA and Hanington PC (2019) A fine- scale phylogenetic assessment of digenean trematodes in central Alberta reveals we have yet to uncover their total diversity. Ecology and Evolution 9, 3153-3238. DOI: 10.1002/ece3.4939.

Katoh K and Standley DM (2013) MAFFT multiple sequence alignment software version 7: improvements in performance and usability. Molecular Biology and Evolution 30, 772-780. DOI: $10.1093 / \mathrm{molbev} / \mathrm{mst} 010$.

Kinkar L, Korhonen PK, Cai H, Gauci CG, Lightowlers MW, Saarma U, Jenkins DJ, Li J, Li J, Young ND and Gasser RB (2019) Long-read sequencing reveals a $4.4 \mathrm{~kb}$ tandemrepeat region in the mitogenome of Echinococcus granulosus (sensu stricto) genotype G1. Parasites \& Vectors 12, 238. DOI: 10.1186/s13071-019-3492-x.

Kostadinova A (2005) Family EchinostomatidaeLooss, 1899, in: Gibson DI, Jones A, Bray AR (eds), Keys to the Trematoda, vol. 2, CAB International, Wallingford 2005, pp. 9-64. 
Kumar S, Stecher G and Tamura K (2016) MEGA7: molecular evolutionary genetics analysis version 7.0 for bigger datasets. Molecular Biology and Evolution 33, 1870-1874. DOI: 10.1093/molbev/msw054.

Laslett D and Canback B (2008) ARWEN: a program to detect tRNA genes in metazoan mitochondrial nucleotide sequences. Bioinformatics 24, 172-175. DOI: 10.1093/bioinformatics/btm573.

Le TH, Blair D and McManus DP (2001) Complete DNA sequence and gene organization of the mitochondrial genome of the liver fluke, Fasciola hepatica L. (Platyhelminthes; Trematoda). Parasitology 123, 609-621. DOI: 10.1017/s0031182001008733

Le TH, Blair D and McManus DP (2002) Mitochondrial genomes of parasitic flatworms. Trends in Parasitology 18, 206-213. DOI: 10.1016/S1471-4922(02)02252-3.

\section{Le TH, Nguyen KT, Nguyen NTB, Doan HTT, Agatsuma T and Blair D (2019) The} complete mitochondrial genome of Paragonimus ohirai (Paragonimidae: Trematoda: Platyhelminthes) and its comparison with $P$. westermani congeners and other trematodes. Peer J 7, e7031. DOI: 10.7717/peerj.7031.

Le TH, Nguyen NTB, Nguyen KT, Doan HTT, Dung DT and Blair D (2016) A complete mitochondrial genome from Echinochasmus japonicus supports the elevation of Echinochasminae Odhner, 1910 to family rank (Trematoda: Platyhelminthes). Infection, Genetics and Evolution 45, 369-377. DOI: 10.1016/j.meegid.2016.09.024.

Li Y, Ma XX, Lv QB, Hu Y, Qiu HY, Chang QC and Wang CR (2019a) Characterization of the complete mitochondrial genome sequence of Tracheophilus cymbius (Digenea), the first representative from the family Cyclocoelidae. Journal of Helminthology 94, e101. DOI: 10.1017/S0022149X19000932. 
Li Y, Qiu YY, Zeng MH, Diao PW, Chang QC, Gao Y, Zhang Y and Wang CR (2019b) The complete mitochondrial genome of Echinostoma miyagawai: Comparisons with closely related species and phylogenetic implications. Infection, Genetics and Evolution 75, 103961. DOI: 10.1016/j.meegid.2019.103961.

Littlewood DT, Lockyer AE, Webster BL, Johnston DA and Le TH (2006) The complete mitochondrial genomes of Schistosoma haematobium and Schistosoma spindale and the evolutionary history of mitochondrial genome changes among parasitic flatworms. Molecular Phylogenetics and Evolution 39, 452-467. DOI: 10.1016/j.ympev.2005.12.012.

Liu GH, Gasser RB, Young ND, Song HQ, Ai L and Zhu XQ (2014) Complete mitochondrial genomes of the 'intermediate form' of Fasciola and Fasciola gigantica, and their comparison with F. hepatica. Parasites \& Vectors 7, 150. DOI: 10.1186/1756-3305-7-150.

Lowe TM and Eddy SR (1997) tRNAscan-SE: a program for improved detection of transfer RNA genes in genomic sequence. Nucleic Acids Research 25, 955-964. DOI: 10.1093/nar/25.5.955.

Lunt DH, Whipple LE and Hyman BC (1998) Mitochondrial DNA variable number tandem repeats (VNTRs): utility and problems in molecular ecology. Molecular Ecology 7, 14411455. DOI: $10.1046 / j .1365-294 x .1998 .00495 . x$

Ma J, He JJ, Liu GH, Leontovyč R, Kašný M and Zhu XQ (2016) Complete mitochondrial genome of the giant liver fluke Fascioloides magna (Digenea: Fasciolidae) and its comparison with selected trematodes. Parasites \& Vectors 9, 429. DOI: 10.1186/s13071016-1699-7.

Ma J, Sun MM, He JJ, Liu GH, Ai L, Chen MX and Zhu XQ (2017) Fasciolopsisbuski (Digenea: Fasciolidae) from China and India may represent distinct taxa based on 
mitochondrial and nuclear ribosomal DNA sequences. Parasites \& Vectors 10, 101. DOI: 10.1186/s13071-017-2039-2.

Miliotis MD and Bier JW (2003) International handbook of foodborne pathogens. CRC Press, New York.

Nagataki M, Tantrawatpan C, Agatsuma T, Sugiura T, Duenngai K, Sithithaworn P, Andrews RH, Petney TN and Saijuntha W (2015) Mitochondrial DNA sequences of 37 collar-spinedechinostomes (Digenea: Echinostomatidae) in Thailand and Lao PDR reveals presence of two species: Echinostoma revolutum and E. miyagawai. Infection, Genetics and Evolution 35, 56-62. DOI: 10.1016/j.meegid.2015.07.022.

Oey H, Zakrzewski M, Narain K, Devi KR, Agatsuma T, Nawaratna S, Gobert GN, Jones MK, Ragan MA, McManus DP and Krause L (2019) Whole-genome sequence of the oriental lung fluke Paragonimus westermani. Gigascience 8, giy146. DOI: 10.1093/gigascience/giy146.

Olson PD, Cribb TH, Tkach VV, Bray RA and Littlewood DTJ (2003) Phylogeny and classification of the Digenea (Platyhelminthes: Trematoda). International Journal for Parasitology 33, 733-755. DOI: 10.1016/S0020-7519(03)00049-3.

Perna NT and Kocher TD (1995) Patterns of nucleotide composition at fourfold degenerate sites of animal mitochondrial genomes. Journal of Molecular Evolution 41, 353-358. DOI: 10.1007/BF00186547.

\section{Saijuntha W, Sithithaworn P, Duenngai K, Kiatsopit N, Andrews RH and Petney TN}

(2011a) Genetic variation and relationships of four species of medically important echinostomes (Trematoda: Echinostomatidae) in South-East Asia. Infection, Genetics and Evolution 11, 375-381. DOI: 10.1016/j.meegid.2010.11.009. 
Saijuntha W, Tantrawatpan C, Sithithaworn P, Andrews RH and Petney TN (2011b)

Genetic characterization of Echinostoma revolutum and Echinoparyphium recurvatum (Trematoda: Echinostomatidae) in Thailand and phylogenetic relationships with other isolates inferred by ITS1 sequence. Parasitology Research 108, 751-755. DOI:

10.1007/s00436-010-2180-8.

\section{Saijuntha W, Tantrawatpan C, Sithithaworn P, Andrews RH and Petney TN (2011c)}

Spatial and temporal genetic variation of Echinostoma revolutum (Trematoda:

Echinostomatidae) from Thailand and the Lao PDR. Acta Tropica 118, 105-109. DOI: 10.1016/j.actatropica.2011.02.014.

Suleman, Khan MS, Heneberg P, Zhou CY, Muhammad N, Zhu XQ and Ma J (2019) Characterization of the complete mitochondrial genome of Uvitellina sp., representative of the family Cyclocoelidae and phylogenetic implications. Parasitology Research 118, 22032211. DOI: $10.1007 / \mathrm{s} 00436-019-06358-y$.

Tkach VV, Kudlai O and Kostadinova A (2016) Molecular phylogeny and systematics of the Echinostomatoidea Looss, 1899 (Platyhelminthes: Digenea). International Journal for Parasitology 46, 171-185. DOI: 10.1016/j.ijpara.2015.11.001

Toledo R and Esteban JG (2016). An update on human echinostomiasis. Transactions of the Royal Society of Tropical Medicine and Hygiene 110, 37-45. DOI: org/10.1093/trstmh/trv099

Wey-Fabrizius AR, Podsiadlowski L, Herlyn H and Hankeln T (2013) Platyzoan mitochondrial genomes. Molecular Phylogenetics and Evolution 69, 365-375. DOI: 10.1016/j.ympev.2012.12.015. 


\section{Yang X, Gasser RB, Koehler AV, Wang L, Zhu K, Chen L, Feng H, Hu M and Fang R}

(2015) Mitochondrial genome of Hypoderaeum conoideum - comparison with selected trematodes. Parasites \&Vectors 8, 97. DOI: 10.1186/s13071-015-07c20-x. 
Table1. Primers for amplification and sequencing fragments of mitochondrial genome of Echinostoma revolutum

\begin{tabular}{|c|c|c|}
\hline Primer & Sequence (5' to 3') & Location \\
\hline ERE1F & GGTCTTATTCTKGCTATGGCTGC & $\operatorname{cox} 1$ \\
\hline ERE2R & AGCCGACTACGAGTTCCAC & $\operatorname{cox} 1$ \\
\hline ERE3F & TGCTTAGTTGTGTTCGTTCTGC & $n a d 1$ \\
\hline ERE4R & CCTAAGACCACACAATAACCGC & nad 1 \\
\hline ERE5F & CTATGTGCTGCTGATGTTGGG & $r r n \mathrm{~S}$ \\
\hline ERE6R & GATGCTGGCACTGTGTATCC & $r r$ \\
\hline$\overline{\text { ERE7F }}$ & TTTCAGCCCATGTTTGTTTAGC & \\
\hline ERE8R & ACAAAGAGGGGATTGTTTGAACC & cytb \\
\hline ERE9F & ATCTGGTTTTGGGTTTCGGG & nad5 \\
\hline ERE10R & AACCAAAGCCGCAAAAGAGG & nad5 \\
\hline ERE11F & AGATGCTATACCCGGACGTC & $\cos 2$ \\
\hline ERE12R & ACCACCTCACACACCAATCA & $\operatorname{cox} 1$ \\
\hline ERE13R & CACAAAGAGTGGCAAGCTCC & nad2 \\
\hline ERE16F & AGAATTTTGGCTTGTCGTGCC & $\operatorname{trn} \mathrm{D}$ \\
\hline ERE17R & CTAACACCCCCTATAAACCCAG & nad4 \\
\hline ERE18R & ACTCTGATGTTGGGGTGTTGG & $\operatorname{cox} 1$ \\
\hline ERE19F & GTGTGGTTTCATTTTATCGTTGGGAGG & nad5 \\
\hline ERE20R & CAACCCAAGCTTTATACATAGGCAACC & $\cos 3$ \\
\hline ERE21R & AGGAACAACAAACTCCTCCTC & $\cos 3$ \\
\hline ECH3F & ATGAKTTGRTTGCCWATRTATAAAGC & $\cos 3$ \\
\hline ERE22F & AATGGGCAATTAAATTTGATGTGG & NCR \\
\hline ERE23R & CATTGCCATACAGCAAATGCCAATC & NCR \\
\hline
\end{tabular}


Table 2. Locations of genes and other features in the complete mitochondrial genome of Echinostoma revolutum (17,030 bp) (GenBank: MN496162)

\begin{tabular}{|c|c|c|c|c|}
\hline Gene & $\begin{array}{l}\text { Position } \\
\left(5^{\prime}>3^{\prime}\right)\end{array}$ & $\begin{array}{c}\text { Characteristics } \\
{[\text { bp/aa(start/stop)] }} \\
\text { and regions }\end{array}$ & $\begin{array}{l}\text { tRNA } \\
\text { anti- } \\
\text { codon }\end{array}$ & $\begin{array}{l}\text { Int. seq. } \\
\text { length } \\
\text { (bp) }\end{array}$ \\
\hline $\cos 3$ & $1-645$ & 645/214/(ATG/TAA) & & +3 \\
\hline $\mathrm{tRNA}^{\mathrm{His}}$ & $649-719$ & 71 & GTG & +2 \\
\hline$c y t \mathrm{~b}$ & $722-1831$ & 1110/369/(ATG/TAG) & & \\
\hline $\operatorname{nad} 4 \mathrm{~L}$ & $1832-2104$ & 273/90/(GTG/TAA) & & \\
\hline nad4 & $2065-3348$ & 1284/427/(ATG/TAA) & & -4 \\
\hline $\mathrm{tRNA}^{\mathrm{Gln}}$ & $3353-3415$ & 63 & & +12 \\
\hline tRNA $^{\text {Phe }}$ & $3428-3491$ & 64 & A & +26 \\
\hline tRNA $^{\text {Met }}$ & $3518-3583$ & & CAT & +3 \\
\hline atp6 & $3587-4105$ & 519/172/(ATG/TAA) & & +12 \\
\hline nad 2 & $4118-4987$ & 870/289/(GTG/TAG) & & +6 \\
\hline $\mathrm{tRNA}^{\mathrm{Val}}$ & 4994-5056 & 63 & TAC & +30 \\
\hline tRNA ${ }^{\text {Ala }}$ & $5087-5153$ & 67 & TGC & +1 \\
\hline $\mathrm{tRNA}^{\mathrm{Asp}}$ & $5155-5220$ & 65 & GTC & 0 \\
\hline $\operatorname{nad} 1$ & $5221-6129$ & 909/302/(GTG/TAG) & & +13 \\
\hline $\mathrm{tRNA}^{\mathrm{Asn}}$ & $6143-6209$ & 67 & GTT & +4 \\
\hline $\mathrm{tRNA}^{\text {Pro }}$ & $6214-6280$ & 67 & TGG & +1 \\
\hline ttRNA ${ }^{\text {Ile }}$ & $6282-6343$ & 62 & GAT & +14 \\
\hline tRNA $^{\text {Lys }}$ & $6358-6425$ & 68 & CTT & +4 \\
\hline nad3 & $6430-6786$ & 357/118/(ATG/TAG) & & +2 \\
\hline
\end{tabular}




\begin{tabular}{|c|c|c|c|c|}
\hline $\operatorname{tRNA}^{\operatorname{Serl}(\mathrm{AGN}) *}$ & 6789-6848 & 60 & GCT & +7 \\
\hline $\mathrm{tRNA}^{\operatorname{Trp}}$ & $6856-6921$ & 66 & TCA & +3 \\
\hline $\operatorname{cox} 1$ & $6925-8463$ & 1539/512/(GTG/TAG) & & +33 \\
\hline $\mathrm{tRNA}^{\mathrm{Thr}}$ & $8497-8562$ & 66 & TGT & 0 \\
\hline $\operatorname{rrnL}(16 S)$ & $8563-9539$ & 977 & & 0 \\
\hline $\mathrm{tRNA}^{\mathrm{Cys}}$ & $9540-9605$ & 66 & GCA & 0 \\
\hline$r r n \mathrm{~S}(12 \mathrm{~S})$ & 9606-10359 & 756 & & 0 \\
\hline $\operatorname{cox} 2$ & $10360-10968$ & 609/201/(ATG/TAA) & & +11 \\
\hline nad6 & $10980-11432$ & 453/150/(ATG/TAG) & & \\
\hline $\mathrm{tRNA}^{\mathrm{Tyr}}$ & $11433-11497$ & 65 & & +11 \\
\hline $\mathrm{tRNA}^{\mathrm{Leul}(\mathrm{CUN})}$ & $11498-11561$ & 64 & & -2 \\
\hline $\operatorname{tRNA}^{\operatorname{Ser} 2(\mathrm{UCN}) *}$ & $11560-11624$ & 65 & & +10 \\
\hline $\mathrm{tRNA}^{\mathrm{Leu2(UUR)}}$ & $11635-11697$ & & TAA & -2 \\
\hline $\mathrm{tRNA}^{\mathrm{Arg}}$ & $11696-11762$ & & TCG & -2 \\
\hline nad5 & $11761-13326$ & 1566/521/(GTG/TAG) & & +12 \\
\hline $\mathrm{tRNA}^{\mathrm{Gly}}$ & $13339-1340$ & 67 & TCC & +11 \\
\hline $\mathrm{tRNA}^{\text {Glu }}$ & 13417-13481 & 65 & TTC & +7 \\
\hline Repeat units & $13489-16912$ & & & \\
\hline LRU1 & 13489-13805 & 317 & & 0 \\
\hline LRU2 & $13806-14122$ & 317 & & 0 \\
\hline LRU3 & $14123-14439$ & 317 & & 0 \\
\hline LRU4 & $14440-14756$ & 317 & & 0 \\
\hline LRU5 & $14757-15073$ & 317 & & 0 \\
\hline LRU6 & $15074-15390$ & 317 & & 0 \\
\hline
\end{tabular}


$\begin{array}{llll}\text { LRU7 } & 15391-15707 & 317 & 0\end{array}$

$\begin{array}{cccc}\text { Int. Spacer } & 15708-16341 & 377 & 0 \\ \text { IntS-half } 1 & 15708-15895 & 188 & 0 \\ \text { IntS-half } 2 & 15896-16084 & 189 & 0 \\ \text { SRU4 } & 16085-16291 & 207 & 0 \\ \text { SRU3 } & 16292-16498 & 207 & 0 \\ \text { SRU2 } & 16499-16705 & 207 & 0 \\ \text { SRU1 } & 16706-16912 & 207 & 0 \\ \text { unique seq } & 16913-17030 & 130 & \end{array}$

bp: basepair; aa: amino acid; start: start codon; stop: stop codon; Int. seq.: intergenic sequence (+. number of nucleotides before start of following gene; -, number of nucleotides overlapping with following gene);

*Asterisk: tRNAs lacking DHU-arm. LRU: Long repeat unit;SRU: Short repeat unit; IntS: internal spacer sequence between LRU7 and SRU4; unique seq: nucleotide sequence between SRU1 and cox3. 
Table 3. Base composition and skewness value for the mitochondrial protein-coding (PCGs) and mitoribosomal genes (MRGs) of 15 members of the superfamily Echinostomatoidea

\begin{tabular}{|c|c|c|c|c|c|c|c|c|c|c|c|}
\hline & Species & & $\begin{array}{c}\text { Length } \\
\text { (nt) }\end{array}$ & $\begin{array}{c}A \\
(\%)\end{array}$ & $\begin{array}{c}\mathrm{T} \\
(\%)\end{array}$ & $\begin{array}{c}\mathbf{G} \\
(\%)\end{array}$ & $\begin{array}{c}\mathrm{C} \\
(\%)\end{array}$ & $\begin{array}{c}\mathbf{A + T} \\
(\%)\end{array}$ & $\begin{array}{c}\text { AT- } \\
\text { skew }\end{array}$ & $\begin{array}{c}\text { G+C } \\
(\%)\end{array}$ & $\begin{array}{c}\text { GC- } \\
\text { skew }\end{array}$ \\
\hline & ECHINOSTOMATIDAE & & & & & & & & & & \\
\hline \multirow[t]{2}{*}{1} & Echinostoma revolutum & PCGs & 10,134 & 18.81 & 47.40 & 23.50 & 10.29 & 62.21 & -0.460 & 37.79 & 0.391 \\
\hline & & MRGs & 1,733 & 25.74 & 36.99 & 23.77 & 13.50 & 62.73 & -0.179 & 37.27 & 0.275 \\
\hline \multirow[t]{2}{*}{2} & Artyfechinostomum sufrartyfex & PCGs & 10,131 & 16.99 & 46.21 & 26.53 & 10.27 & 63.20 & -0.462 & 36.80 & 0.442 \\
\hline & & MRGs & 1,728 & 24.71 & 3.709 & 25.58 & 12.62 & 61.80 & -0.20 & 38.20 & 0.339 \\
\hline \multirow[t]{2}{*}{3} & Echinostoma caproni & PCGs & 10,128 & 17.34 & 47.82 & 24.79 & 10.05 & 65.16 & -0.468 & 34.84 & 0.423 \\
\hline & & MRGs & 1,709 & 25.34 & 36.63 & 24.40 & 13.63 & 61.97 & -0.182 & 38.03 & 0.283 \\
\hline \multirow[t]{2}{*}{4} & Echinostoma miyagawai & PCGs & 10,128 & 18.20 & 47.65 & 24.07 & 10.08 & 65.85 & -0.447 & 34.15 & 0.410 \\
\hline & & MRGs & 1,724 & 25.75 & 37.94 & 23.49 & 12.82 & 63.72 & -0.191 & 36.31 & 0.294 \\
\hline \multirow[t]{2}{*}{5} & Echinostoma paraensei & PCGs & 10,128 & 18.04 & 47.57 & 24.13 & 10.26 & 65.61 & -0.450 & 34.39 & 0.403 \\
\hline & & MRGs & 1,748 & 25.92 & 37.76 & 23.68 & 12.64 & 63.68 & -0.186 & 36.32 & 0.304 \\
\hline \multirow[t]{2}{*}{6} & Echinostoma sp. JM-2019 & PCGs & 10,122 & 16.47 & 46.46 & 26.66 & 10.40 & 62.93 & -0.477 & 37.60 & 0.432 \\
\hline & & MRGs & 1,726 & 24.51 & 35.17 & 26.94 & $13 . .38$ & 59.68 & -0.179 & 40.32 & 0.336 \\
\hline \multirow[t]{3}{*}{7} & Hypoderaeum conoideum & PCGs & 10,116 & 16.84 & 45.25 & 26.96 & 10.95 & 62.09 & -0.458 & 37.91 & 0.422 \\
\hline & & MRGs & 1,730 & 25.14 & 34.68 & 26.59 & 13.58 & 59.82 & -0.159 & 40.17 & 0.324 \\
\hline & ECHINOCHASMIDAE & & 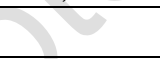 & & & & & & & & \\
\hline \multirow[t]{3}{*}{8} & Echinochasmus japonicus & PCGs & 10,143 & 15.66 & 46.55 & 28.05 & 9.74 & 62.21 & -0.497 & 37.79 & 0.485 \\
\hline & & MRGs & 1,748 & 22.83 & 35.58 & 28.60 & 12.99 & 58.41 & -0.218 & 41.65 & 0.375 \\
\hline & FASCIOLIDAE & & & & & & & & & & \\
\hline \multirow[t]{2}{*}{9} & Fasciola hepatica & PCGs & 10,104 & 14.29 & 49.24 & 26.90 & 9.57 & 63.53 & -0.550 & 36.47 & 0.475 \\
\hline & & & 1,755 & 23.10 & 39.25 & 26.13 & 11.52 & 62.35 & -0.259 & 37.65 & 0.388 \\
\hline & Fasciola gigantica & PCGs & 10,107 & 13.53 & 50.44 & 27.28 & 8.76 & 63.97 & -0.577 & 36.04 & 0.514 \\
\hline & & MRGs & 1,755 & 21.29 & 40.18 & 27.32 & 11.21 & 61.47 & -0.307 & 38.53 & 0.418 \\
\hline & Fasciola jacksoni & PCGs & 10,137 & 14.71 & 46.97 & 29.09 & 9.23 & 61.68 & -0.523 & 38.52 & 0.516 \\
\hline & & MRGs & 1,743 & 24.38 & 38.50 & 26.56 & 10.56 & 62.88 & -0.225 & 37.12 & 0.431 \\
\hline & Fascioloides magna & PCGs & 10,131 & 15.41 & 46.59 & 28.29 & 9.71 & 62.0 & -0.503 & 38.00 & 0.489 \\
\hline & & MRGs & 1,751 & 23.24 & 38.26 & 26.50 & 11.99 & 61.50 & -0.224 & 38.49 & 0.377 \\
\hline
\end{tabular}




\begin{tabular}{|c|c|c|c|c|c|c|c|c|c|c|c|}
\hline \multirow[t]{2}{*}{13} & Fasciolopsis buski & $\begin{array}{l}\text { PCGs } \\
\text { MRGs }\end{array}$ & $\begin{array}{c}10,122 \\
1,768\end{array}$ & $\begin{array}{l}16.62 \\
24.38 \\
\end{array}$ & $\begin{array}{l}48.97 \\
40.27 \\
\end{array}$ & $\begin{array}{l}25.81 \\
24.43 \\
\end{array}$ & $\begin{array}{c}8.61 \\
10.92 \\
\end{array}$ & $\begin{array}{l}65.59 \\
64.65 \\
\end{array}$ & $\begin{array}{l}-0.493 \\
-0.246 \\
\end{array}$ & $\begin{array}{l}34.42 \\
35.35 \\
\end{array}$ & $\begin{array}{l}0.500 \\
0.382\end{array}$ \\
\hline & HIMASTHLIDAE & & & & & & & & & & \\
\hline \multirow[t]{3}{*}{14} & Acanthoparyphium sp.WAK-2018 & PCGs & 10,119 & 17.20 & 44.93 & 26.83 & 11.05 & 62.13 & -0.446 & 37.87 & 0.417 \\
\hline & & MRGs & 1,753 & 24.70 & 36.74 & 25.90 & 12.66 & 61.44 & -0.196 & 38.56 & 0.343 \\
\hline & CYCLOCOELIDAE & & & & & & r & & & & \\
\hline \multirow[t]{2}{*}{15} & Tracheophilus cymbius & PCGs & 10,152 & 14.83 & 48.78 & 27.17 & 09.22 & 63.61 & -0.534 & 36.39 & 0.493 \\
\hline & & MRGs & 1,745 & 22.58 & 38.34 & 27.05 & 12.03 & 60.92 & -0.411 & 39.08 & 0.384 \\
\hline
\end{tabular}


Table 4. Nucleotide comparison for divergence rate (\%) of individual and concatenated protein-coding (PCGs) and mitoribosomal genes

(MRGs) between Echinostoma revolutum and 14 representative members of the superfamily Echinostomatoidea (Platyhelminthes:

Echinostomata)

\begin{tabular}{|c|c|c|c|c|c|c|c|c|c|c|c|c|c|c|c|c|}
\hline \multirow{3}{*}{ Species } & \multirow{2}{*}{\multicolumn{13}{|c|}{ Echinostoma revolutum }} & \multirow{2}{*}{\multicolumn{3}{|c|}{$\begin{array}{c}\text { Mitoribosomal } \\
\text { genes }\end{array}$}} \\
\hline & & & & & & & & & & & & & & & & \\
\hline & atp6 & $\operatorname{cox} 1$ & $\cos 2$ & $\operatorname{cox} 3$ & cytb & nad1 & nad2 & nad3 & nad4L & nad4 & nad5 & nad6 & PCGs & $r r n \mathrm{~L}$ & $r r n S$ & MRC \\
\hline 1 Ecap & 19.85 & 15.76 & 14.72 & 14.67 & 15.15 & 15.67 & 18.19 & 13.50 & & 19.91 & 19.77 & 20.03 & 17.20 & 12.19 & 6.93 & 10.53 \\
\hline 2 Emiy & 16.98 & 12.62 & 11.73 & 13.29 & 12.61 & 12.84 & & & & & 17.25 & 19.26 & & & 6.63 & \\
\hline 3 Epar & 21.16 & 15.46 & 14.27 & 14.64 & 13.87 & 14.54 & 17.81 & 14.82 & 1 & 2 & 17.19 & 17.33 & 10 & 56 & 7.16 & 08.84 \\
\hline 4 EJM & 31.37 & 19.24 & 18.60 & 22.62 & 19.29 & 22.59 & 29.17 & 23.17 & & .75 & 28.57 & 1.37 & 58 & 21.83 & 15.48 & 19.53 \\
\hline 5 Asuf & 31.60 & 21.75 & 20.65 & 25.57 & 20.53 & 24.27 & 33.03 & 23.39 & 22.10 & 35.33 & 32.66 & 34.36 & 26.74 & 22.82 & 19.15 & 21.47 \\
\hline 6 Hcon & 37.00 & 23.52 & 33.68 & 27.90 & 22.07 & 23.70 & 34.22 & 28.22 & 22.17 & 19 & 32.65 & 31.77 & 67 & 17 & 55 & .33 \\
\hline 7 Ejap & 43.08 & 30.63 & 49.45 & 48.80 & 28.25 & 30.81 & 48.05 & 32.81 & & 45.08 & 41.84 & 41.63 & & 30.43 & 34.37 & 32.37 \\
\hline 8 Fhep & 39.80 & 25.38 & 39.90 & 42.21 & 26.22 & 23.07 & & & & & 41.92 & 42.33 & & 31 & 0 & 31.23 \\
\hline 9 Fgig & 37.35 & 24.17 & 40.36 & 40.31 & 26.54 & 24.17 & 44.46 & & & & 38.49 & 43.07 & & 31.86 & & 30.77 \\
\hline 10 Fjac & 40.08 & & & 46.65 & 29.02 & 26.48 & & & & & 42.25 & 45.72 & & 59 & & 66 \\
\hline 11 Fmag & 39.89 & 25.04 & 42.86 & 46.52 & 28.60 & 26.55 & 42.06 & 31.67 & & 42.07 & 41.94 & 53.90 & & 33.27 & 26.49 & 30.31 \\
\hline 12 Fbus & 37.25 & 26.61 & 37.69 & 40.36 & 25.21 & 25.52 & 43.87 & 30.91 & & & 43.66 & 43.34 & & 31.94 & 27.90 & 31.50 \\
\hline 13 AWAK & 38.07 & 29.92 & 41.64 & 41.46 & 27.07 & 32.50 & 47.07 & 33.53 & 30.57 & 46.85 & 45.17 & 38.88 & 37.43 & 32.78 & 26.99 & 31.32 \\
\hline 14 Tcym & 48.98 & 26.81 & 41.49 & 43.27 & 28.08 & 30.74 & 44.84 & 30.56 & 33.15 & 52.29 & 59.89 & 47.32 & 39.50 & 30.69 & 28.28 & 31.72 \\
\hline
\end{tabular}

Ecap: Echinostomacaproni; Emiy: E. miyagawai; Epar: E. paraensei; EJM: Echinostoma sp. JM-2019; Asuf: Artyfechinostomum sufrartyfex;

Hcon: Hypoderaeum conoideum; Ejap: Echinochasmus japonicus; Fhep: Fasciola hepatica; Fgig: F. gigantica; Fjac: F. gigantica; Fmag:

Fascioloides magna; Fbus: Fasciolopsis buski; AWAK: Acanthoparyphium sp. WAK-2018; Tcym: Tracheophilus cymbius. 
Table 5. Number and type of the repetitive sequences in non-coding regions (NCR) of 15 representative members of the superfamily

Echinostomatoidea indicating high polymorphism and interspecific/intergeneric variation.

\begin{tabular}{|c|c|c|c|c|c|c|}
\hline & Species & $\begin{array}{c}\text { Length of NCR } \\
\text { (bp) }\end{array}$ & $\begin{array}{c}\text { Number and size } \\
\text { of repeat units (RU) }\end{array}$ & Type of repeat units & $\begin{array}{c}\text { Accession } \\
\text { No }\end{array}$ & References \\
\hline 1 & Echinostoma revolutum & 3,549 & $\begin{array}{l}7 \text { LRUs (317 bp/each) } \\
4 \text { SRUs (207 bp/each) }\end{array}$ & Tandem repeat family & MN496162 & This study \\
\hline 2 & Echinostoma caproni & 685 & none & none & AP017706 & GenBank \\
\hline 3 & Echinostoma miyagawai & 982 & 2 RUs (319 bp/each) & Tandem repeat family & MN116740 & Fu et al., 2019 \\
\hline 4 & Echinostoma paraensei* & 6,798 & 3 RUs (206 bp/each) & Tandem repeat family & KT008005 & GenBank \\
\hline 5 & Echinostoma sp. JM-2019 & 1,877 & $\begin{array}{l}5 \text { LRUs (245 bp/each) } \\
2 \text { SRUs (166 bp/each) }\end{array}$ & Tandem repeat family & MH212284 & GenBank \\
\hline 6 & Artyfechinostomum sufrartyfex & 1,004 & 2 RUs (144 bp/each) & Tandem repeat family & KY548763 & GenBank \\
\hline 7 & Hypoderaeum conoideum & 654 & & none & KM111525 & $\begin{array}{l}\text { Yang et al., } \\
2015\end{array}$ \\
\hline 8 & Echinochasmus japonicus & 2,001 & 8 RUs (240 bp/each) & Tandem repeat family & KP844722 & Le et al., 2016 \\
\hline 9 & Fasciola hepatica & 817 & 9 RUs ( 85 bp/each) & Tandem repeat family & AF216697 & Le et al., 2001 \\
\hline 10 & Fasciola gigantica & 841 & 8 RUs ( 86 bp/each) & Tandem repeat family & KF543342 & $\begin{array}{l}\text { Liu et al., } \\
2014\end{array}$ \\
\hline 11 & Fasciola jacksoni & 1,51 & 9 RUs (113 bp/each) & Tandem repeat family & KX787886 & GenBank \\
\hline 12 & Fascioloides magna & & 5 RUs (60 bp/each) & Tandem repeat family & KU060148 & $\begin{array}{c}\text { Ma et al., } \\
2016\end{array}$ \\
\hline 13 & Fasciolopsis buski & & 8 RUs (104 bp/each) & Tandem repeat family & KX169163 & $\begin{array}{l}\text { Ma et al., } \\
2017\end{array}$ \\
\hline 14 & Acanthoparyphium sp. WAK-2018 & 723 & 3 RUs (57 bp/each) & Tandem repeat family & MG792058 & GenBank \\
\hline 15 & Tracheophilus cymbius & 142 & none & none & MK355447 & $\begin{array}{c}\text { Li et al., } \\
2019 \mathrm{a}\end{array}$ \\
\hline
\end{tabular}

*non-coding region in E. paraensei not fully sequenced. 


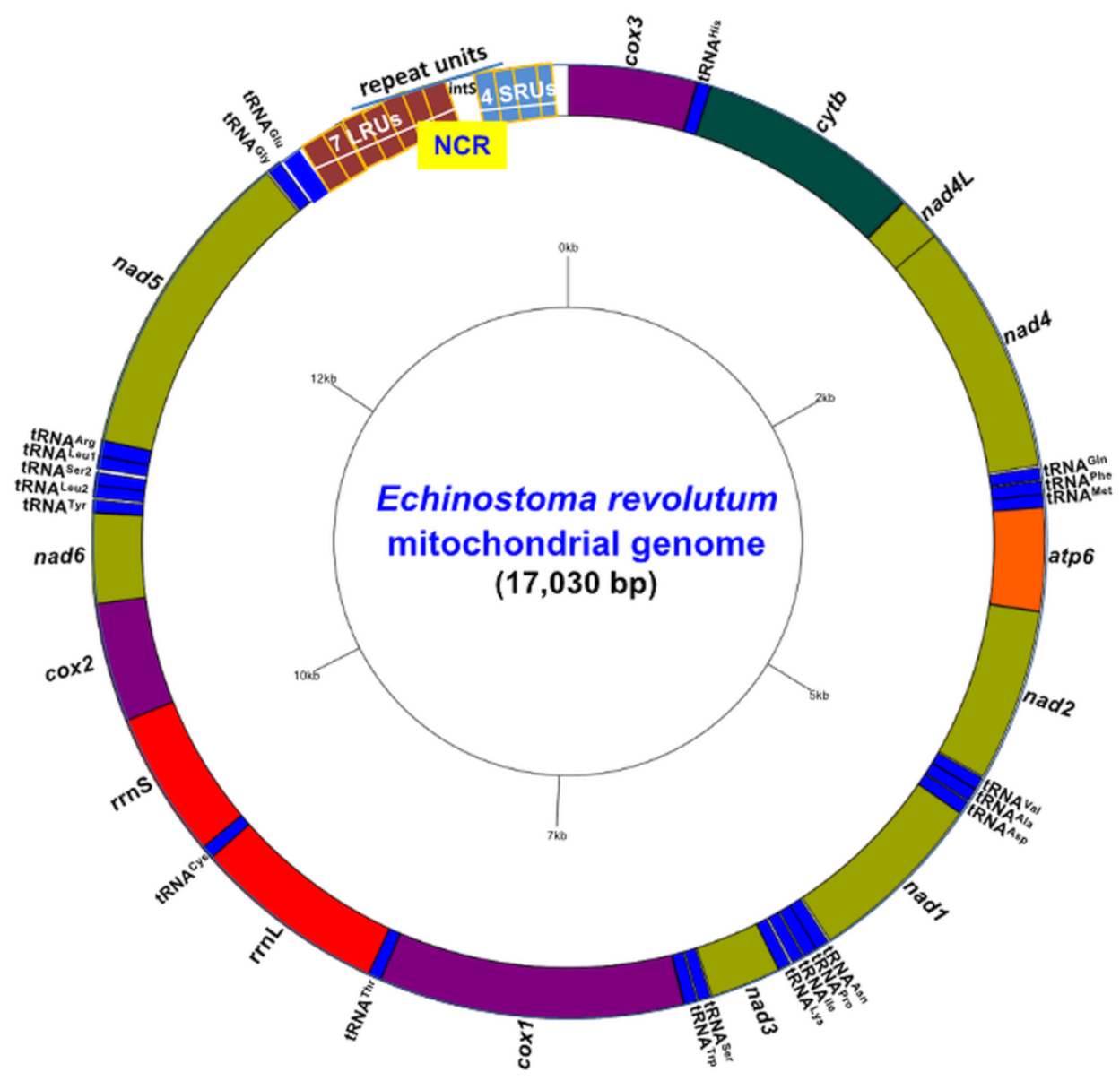

Figure 1. A schematic drawing of circular map of the mitochondrial genome of Echinostoma revolutum (GenBank: MN496162). Protein-coding and ribosomal large and small subunit genes are abbreviated according to our previous publications (Le et al., 2016; 2019). The transfer RNA genes (tRNA) are marked with three letter-amino acid abbreviations (see: Table 2). The non-coding region (NCR) located between tRNA ${ }^{\mathrm{Glu}}$ and $\operatorname{cox} 3$, consists of seven long (LRU1-7), 4 short repeat units (SRU1-4) and internal spacer sequence (IntS) between LRU7 and SRU4. 


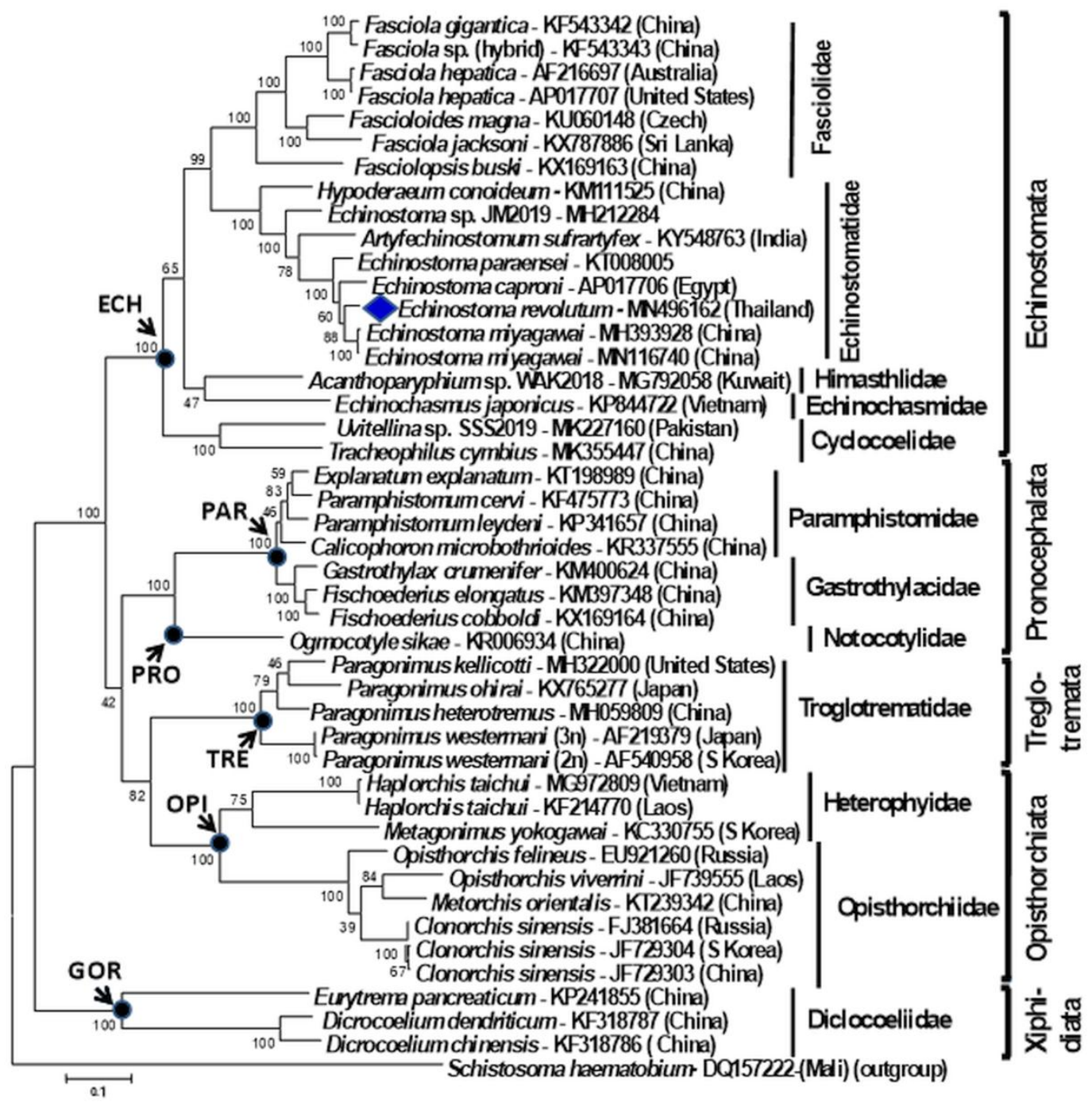

Figure 2. A maximum likelihood phylogenetic tree showing the position of Echinostoma revolutum (diamond symbol) based on analysis of concatenated amino-acid sequence data for the 12 mitochondrial proteins of 45 digenean species/strains. Thirteen families (Echinostomatidae, Fasciolidae, Himasthlidae, Echinochasmidae, Cyclocoelidae, Paramphistomidae, Gastrothylacidae, Notocotylidae, Troglotrematidae/ (Paragonimidae), Heterophyidae, Opisthorchiidae, Diclocoeliidae and Schistosomatidae), belonging to six superfamilies indicated by arrows, Echinostomatoidea (ECH), Paramphistomoidea (PAR), Pronocephaloidea (PRO), Treglotrematoidea (TRE), Opisthorchioidea 
(OPI) and Gorgoderoidea (GOR) are represented. Schistosoma haematobium (Platyhelminthes:

Schistosomatidae) is included as an outgroup. Nodal support values evaluated using 1000 bootstrap resamplings are shown on each branch. The scale bar represents the number of substitutions per site. Accession numbers are given for each species/strains and country name (in bracket) of their origin (where available) at the end of each sequence. 